\title{
The search for a Law of the Sea
}

THE coastal states of the world, in particular those with wide continental shelves, have for ten years now been working on certain principles: what we can grab by inventing new rules, we will claim for ourselves; what's left can be designated as a common heritage of mankind; and the profits therefrom (if there are any) can be shared amongst States Parties to the Convention (including ourselves) but (as a sop) "taking into particular consideration the interests and the needs of the developing countries". Their object has now nearly been achieved, and it looks as if we shall see in the next year or two a Convention that allocates to the coastal states a 200-mile economic zone plus almost certainly the resources of the continental margin where that margin extends beyond 200 miles. So far as scientific research is concerned, its fate within these zones will be barely distinguishable from that in the Territorial Sea, as it will be tightly controlled by a "consent" regime throughout.

What is left is known as the "Area" -the sea-bed and ocean floor and subsoil thereof (that is, not the water column) beyond the limits of national jurisdiction. These limits of national jurisdiction have not yet been defined; a number of proposals have been made, but what is common to all is that the limits are in deep water, thus ensuring that virtually all exploitable areas are kept firmly within the national jurisdiction of the coastal states.

The United Nations is becoming more adept with each decade at developing white elephants, but the possibilities opening up now as a result of the deliberations of the Third UN Conference on the Law of the Sea are even wider.

To control and supervise exploitation of the mineral sources of the Area, there will be an International Sea-bed Authority which has the potential of developing a secretariat several hundred strong with "regional centres or offices" and all the trappings of a UN specialised agency. Added to this, the Authority will have an Enterprise to carry out its activities in the Area. This Enterprise will have a "Board of Governors, a Director-General and such other officers and staff to perform such duties as the Enterprise may determine".

The task of the Authority and its Enterprise will be to extract and market mineral resources from that part of the earth's crust that is physically most difficult, and economically most costly, to exploit, with the proviso that in so doing they must not upset the world's money markets in these commodities. As there is little likelihood of the Authority and its Enterprise becoming a profit making concern in the foreseeable future, here is a golden opportunity for the main financing member states of the United Nations and its specialised agencies to pour millions of dollars into an activity of doubtful economic or social relevance for legalpolitical reasons, instead of into international marine science, food programmes, fisheries and so on, which are being systematically starved of funds in the present world economic state.

The main working document of the conference is known as the "Single Negotiating Text". This first appeared at the end of the third (Geneva) session in mid-1975 and has now been revised as a result of "negotiations" during the fourth (New York) session. The size of the task before the conference (and the UN secretariat) can be realised when it is seen that the latest version of this Single Negotiating Text contains 398 Articles, as well as a number of annexes covering all aspects of the work of the conference. Many of these articles are not acceptable to countries or groups of countries, particularly the landlocked or geographically disadvantaged states which have been very active in asserting their "rights" during the recent session. They are therefore subject to further negotiation. Furthermore, a number of articles are incompatible with others developed in different committees and will need to be reconciled.

One of the mysteries of the conference has been the continued insistence of certain countries on the need to distinguish between fundamental and resource oriented research. This is a completely valueless exercise which in the long run can only do more harm to its promoters, through loss of belief in their honesty and intentions and in goodwill, than a policy of accepting Macmillan's "Winds of Change" and realising that going half way to meet the other man will pay dividends in the long run. The tactics or using a false assumption, one known to be false by the other side, as an item for negotiation are extremely doubtful. The developing countries, the policies of which are formulated by politicians notoriously only concerned with short-term results, and with no tradition of pure research, not surprisingly are unable to believe that developed-country insistence on this point is not a cover for activities which will be detrimental to them, either militarily or commercially. Quite apart from the impossibility of formulating a true distinction, their experience of publicised episodes of this kind, even if in fact minimal in comparison with genuine oceanographic research expeditions, does not augur well for the next so-called negotiating phase of the conference.

The most important outstanding difficulties now appear to be the status of the economic zone, the regime for the deep sea-bed and subsoil and dispute settlement procedures. The USA, which is putting pressure on the conference to reach a conclusion, and whose delegation will be led at the next session by Dr Kissinger himself, has called the arrangements for dispute settlement "the glue of the whole treaty", stating that "without agreed and binding dispute settlement procedures, the treaty will not be adequate".

The President of the conference, $\mathrm{Mr}$ H. Shirley Amerasinghe of Sri Lanka, has proposed that the first two or three weeks of the fifth session be used for inaking attempts to reconcile outstanding differences on the most crucial issues involved in drafting the Convention, followed by indicative but not binding voting in the committee on the various articles in the Single Negotiating Text. Certain delegations have objected to these proposals and it is too early yet to know how the matter will be handled. There is a feeling on many sides that if the conference does not achieve a reasonable consensus by the end of the next session, it will collapse, and no Convention will be possible for many years to come. Should this happen, the conseauences would be endless and could well lead to severe clashes between states on unilaterally imposed limits and restrictions which would almost inevitably be to the disadvantage of the smaller and developing coastal states, owing to their physical inability to patrol and police a 12-mile territorial sea, let alone an economic zone 200 miles or more wide.

The conference was sharply divided on the desirability of holding the next session with only a short recess, in order to keep up the momentum generated in New York, or as a further annual session in Spring 1977. In the event, after an appeal from the President. it was decided to hold the fifth session, from August 2 to September 17, again in UN headquarters, New York. It is honefully envisaged that this will be the final working session and that it will be followed later in the vear, or in earlv 1977 , by the plenipotentiary Conference in Caracas to conclude the Treaty. 